\title{
An Investigation of Preservice English Teachers' Perceptions of Mobile Assisted Language Learning
}

\author{
Huseyin $\mathrm{Oz}^{1}$ \\ ${ }^{1}$ Facult of Education, Hacettepe University, Turkey \\ Correspondence: Huseyin Oz, Hacettepe University, Faculty of Education, Department of Foreign Language \\ Education, Beytepe, Ankara 06800, Turkey. Tel: 90-312-297-8575. E-mail: hoz@hacettepe.edu.tr
}

Received: October 27, 2014 Accepted: November 30, 2014 Online Published: January 20, 2015

doi:10.5539/elt.v8n2p22 URL: http://dx.doi.org/10.5539/elt.v8n2p22

\begin{abstract}
This study aimed to investigate preservice English as a foreign language (EFL) teachers' perceptions about mobile assisted language learning (MALL) and find out whether their perceptions differed by gender, grade level and grade point average (GPA). The study also sought to determine whether gender, grade level and GPA variables would predict their perceptions of MALL. A total of 201 participants enrolled in an EFL teacher education department at a major state university participated in the study and completed the "Mobile Learning Perception Scale." Quantitative data were analyzed using descriptive statistics (means and frequencies, and percentage) and inferential statistics (MANOVA and regression analysis). Findings revealed that overall the participants had high levels of perceptions about MALL, and that gender, grade level and GPA differences moderated the effects of the measured constructs on their perceptions of MALL. All the interviewees expressed their positive attitudes towards using mobile devices in language instruction. The results of multivariate tests indicated a significant main effect for their gender and their perceptions, as well as an interaction effect between gender and GPA. Findings also demonstrated that GPA and gender were the strongest predictors of participants' perceptions about MALL.
\end{abstract}

Keywords: mobile assisted language learning (MALL), preservice English teachers, perceptions, English language learners, mobile devices

\section{Introduction}

Over the last three decades second or foreign language (L2) instruction has been one of the major subject areas of education in which technology has played a central role. As more technologies are integrated in L2 instruction, teachers and learners have more opportunities to get globally connected and educated (Dudeney \& Hockly, 2012). With recent developments in mobile technology, mobile learning (or m-learning) has also attracted considerable attention in the field of L2 instruction (Kukulska-Hulme, 2009; Saran \& Seferoğlu, 2010; Saran, Seferoğlu, \& Çağıltay, 2009, 2012; Stockwell, 2010). Mobile devices such as netbooks, laptops, iPads, tablets, cellular phones, smartphones, digital cameras, mp3 players, personal digital assistants (PDAs), and e-readers have become very widespread, especially among young people (Franklin, 2011). Thus, L2 instruction via mobile devices has become a research and practice trend in technology-enhanced language learning (Godwin-Jones, 2011). Based on the idea of anywhere and anytime learning, m-learning now provides educators with "a myriad of opportunities to support learning and performance both inside and outside the classroom" (Martin \& Ertzberger, 2013, p. 26). It is also fair to suggest that mobile devices can now perform almost all the functions required in learning design (El-Hussein \& Cronje, 2010; Şad \& Göktaş, 2013). Despite ongoing barriers to m-learning such as cost, technical considerations, accessibility, and attitudinal factors (Joint Information Systems Committee [JISC], 2013), the available evidence seems to suggest that m-learning is globally on the rise (Dudeney \& Hockly, 2012; Hockly, 2013).

Whereas m-learning applications are increasingly used for language learning in and outside the classroom (Godwin-Jones, 2011; Hockly, 2013), m-learning research in L2 instruction is still in its infancy when compared to other subject areas of e-learning (Pollara \& Kee Broussard, 2011). Many questions remain to be explored about mobile language learning. The successful integration of m-learning into L2 instruction depends to some degree on students' and teachers' behavioral intention, awareness and perceptual attitudes about mobile language learning. Research into their positive perceptions and attitudes is key to understanding if they will accept and use 
this technology (Pollara \& Kee Broussard, 2011; Şad and Göktaş, 2013). Thus, the present study aims at investigating m-learning perceptions of preservice EFL teachers and find out whether gender, grade level, and grade-point average (GPA) moderate the effects of perceptions on mobile language learning.

Given that m-learning is a new type of learning model, there is not a single agreed-upon definition of it. Some authors view m-learning as an extension of e-learning based on mobile devices (Franklin, 2011), whereas others commonly define it as learning that takes place ubiquitously, anywhere and anytime (Franklin, 2011; Özdamlı \& Çavuç 2011). Does m-learning mean that learners are 'mobile' and that they can learn 'anytime and anywhere'? Does it also suggest that mobile devices are 'portable' and 'mobile'? General definitions often include these two significant aspects of m-learning, i.e. the mobility of learners, and mobility and portability of devices (El-Hussein \& Cronje, 2010; Franklin, 2011). However, equally important is the context in which learning takes place. This means that m-learning involves not only formal learning in the classroom but also "informal and formal learning outside the classroom, across myriad devices, in a variety of physical and temporal arenas" (Hockly, 2013, p. 80). Thus, Sharples et al. (2007) view m-learning as "the processes of coming to know through conversations across multiple contexts amongst people and personal interactive technologies" (p. 225) and emphasize that learning contexts should be created through interaction and portable and ubiquitous technologies.

There is a growing body of evidence suggesting that m-learning provides learners with new opportunities and thus promotes the learning process through interaction and collaboration (Kukulska-Hulme \& Shield, 2008; Kukulska-Hulme, 2009). In their meta-analysis of m-learning issues, Wu et al. (2012) state that a great majority of m-learning studies present positive outcomes associated with such aspects as mobility (El-Hussein \& Cronje, 2010; Şad \& Göktaş, 2013) and informal learning anywhere outside the classroom (Saran et al. 2009), and anytime (Motiwalla, 2007). Similarly, Pollara and Kee Broussard (2011) who focus on learning tasks, perceptions and outcomes conclude that m-learning has instructional value and the potential to positively affect learning in a variety of contexts.

Despite the potential benefits, m-learning is not without its drawbacks. The most cited shortcoming is often ascribed to the small screen sizes which may challenge learning activities (El-Hussein \& Cronje, 2010; Kukulska-Hulme \& Shield, 2008). The limited battery lives and weight of devices such as laptops are problematic (Şad \& Göktaş, 2013). The increasing presence and use of m-learning tools in the classroom may also cause distractions and interruptions (Martin \& Ertzberger, 2013). Others are related to high cost of more functional devices, accessibility and attitudinal factors (Hockly, 2013; JISC, 2013), which might be discouraging in developing countries.

Mobile assisted language learning (MALL) first appeared around 2005, when some USA universities began to give their students free mobile devices (Chinnery, 2006). It came to appear more globally around 2009, when the British Council developed mobile applications (apps) for language learning (Hockly, 2013). Major English language teaching (ELT) publishers producing standalone or coursebook-related apps accelerated the development and spread of MALL globally (Dudeney \& Hockly, 2012). Despite some obstacles to m-learning, it is increasingly becoming widespread both in major subject areas of education (Çavuş \& İbrahim, 2009; El-Hussein \& Cronje, 2010) and in ELT (Godwin-Jones, 2011; Kukulska-Hulme 2009, 2010; Saran et al., 2009, 2012; Saran \& Seferoğlu, 2010). Today large scale MALL projects are conducted in various countries, but m-learning research reports and studies in ELT are still scarce (Godwin-Jones, 2011; Hockly, 2013).

While empirical research into preservice EFL teachers' attitudes towards m-learning is emerging (e.g., Serin, 2012; Tai \& Ting 2011; Uzunboylu \& Özdaml1, 2011), researchers in other fields have conducted numerous studies and demonstrated that students and teachers have positive attitudes and perceptions about m-learning (Çavuş \& İbrahim, 2009; Pollara \& Kee Broussard, 2011; Şad \& Göktaş, 2013; Uzunboylu \& Özdaml1, 2011; Vilberg \& Grönlund, 2013; Wu et al., 2012). Some studies examined variables such as gender, grade level and department. The findings of some studies revealed no significant differences among participants in terms of these variables (Serin, 2012; Şad \& Göktaş, 2013), whereas others revealed that age and gender differences moderate the effects of measured constructs on m-learning (Broos, 2005; Uzunboylu \& Özdaml1, 2011; Vilberg \& Grönlund, 2013; Y. S. Wang, Wu, \& Y. H. Wang, 2009).

There is a rapidly growing literature on attitudes and perceptions about m-learning in education. However, research into preservice EFL teachers' perceptions is partial and scarce (Serin, 2012; Tai \& Ting, 2011; Uzunboylu \& Özdaml, 2011). There is insufficient research into factors that may influence students' readiness, adoption and use of m-learning. Seeing this gap in the current literature, this study aimed to contribute in this respect by investigating preservice English as a foreign language teacher' perceptions of mobile assisted language learning and determining whether there are any differences of perception according to gender, grade 
level and GPA. To this end, the following questions were formulated:

1) What are preservice English as a foreign language (EFL) teacher' perceptions of mobile language learning?

2) Do their mobile language learning perceptions differ significantly according to (a) gender, (b) grade level, and (c) GPA?

3) Do gender, grade level and GPA predict preservice EFL teachers' perceptions of mobile language learning?

It is expected that the findings will shed light upon preservice EFL teachers' intention, awareness and attitudes about mobile assisted language learning and have implications for their training need and use in their future career.

\section{Method}

\subsection{Research Design}

The present study was mainly conducted using a quantitative approach in which a survey instrument was used to gather data about the participants' perceptions about m-learning. In addition, the study was supported with qualitative data drawn from the participants who were interviewed to express their opinions by responding to open-ended questions. Thus, this research was conducted with a mixed-method design in which both quantitative and qualitative data were collected (Dörnyei, 2007). Yet, the bulk of data in the study was quantitatively gathered.

\subsection{Participants}

The participants for this study originally included 220 preservice EFL teachers at a major state university in Ankara, Turkey. Questionnaires were distributed in May 2013. After excluding cases with unreliable or missing data responses among all collected data, 201 cases were obtained and analyzed for the study. The participants were third and fourth grade student-teachers, 156 females $(77.6 \%)$ and 45 males $(22.4 \%)$. The mean age was 21.97 years $(S D=1.29$, range 19-29). To get a better insight into the sample, the participants were asked what mobile devices they had and used, and what options they were using on their mobile devices. Only $11(5 \%)$ of all the participants who fully completed the survey $(N=201)$ did not have laptops or portable PCs. Besides basic calling and texting features, most participants with smartphones reported they used social networking services.

\subsection{Research Instruments}

The instruments for this study included a self-report questionnaire and interview sessions with open-ended questions. The questionnaire consisted of two parts. The first part included questions that characterize the participants such as gender, age, and GPA, while the second part included the Mobile Learning Perception Scale (MLPS) adapted from Uzunboylu and Özdamlı (2011). The scale consists of 26 statements to measure the participants' perceptions of m-learning about three indicators: Aim-Mobile Technologies Fit, Appropriateness of Branch, and Forms of M-learning Application and Tools' Sufficient Adequacy of Communication. The participants rated the statements on a 5-point (ranging from 1. strongly disagree to 5. strongly agree) Likert scale. Internal consistency was examined using Cronbach's alpha value for each variable or dimension as well as the whole scale. Cronbach's alpha value for the whole scale developed by Uzunboylu and Özdamlı (2011) was .97, whereas Cronbach's alpha reliability coefficient was found .96 in this study. The reliability of all variables ranged from .88 to .92 (Table 1). Since all the Cronbach's alpha values of constructs were higher than .70, the instrument was reliable and had good psychometric properties (Field, 2009).

Table 1. Variables and reliabilities

\begin{tabular}{lll}
\hline Variables & Number of Items & Cronbach's Alpha \\
\hline A-MTF-Aim-Mobile Technologies Fit & 8 & .886 \\
AB-Appropriateness of Branch & 9 & .920 \\
FMA and TSAC_-Forms of M-learning Application & 9 & .896 \\
and Tools' Sufficient Adequacy of Communication & 9 & .965 \\
Total & 26 & \\
\hline
\end{tabular}


Because of their convenient accessibility and proximity to the researcher, for qualitative data, fourteen participants were interviewed and asked open-ended questions in Turkish in order to learn about their opinions, thoughts and suggestions about mobile assisted language learning.

\subsection{Procedures for Data Collection and Analysis}

This study was conducted in an undergraduate EFL teacher training department at a major state university in Ankara in May 2013. A great majority of participants enrolled in department courses voluntarily completed a paper-based version of the instrument, whereas others responded to the questions and the statements in the online version of the instrument. Follow-up interviews were held with a total of fourteen participants because of their convenient accessibility and proximity to the researcher, so that they would get the opportunity to express their opinions, thoughts and suggestions about mobile language learning.

To address the research questions, the data were fed into the computer and statistical analyses were conducted using IBM SPSS Statistics 21. In computing the participants' perceptions of m-learning in the MLPS dimensions, the ratings for the corresponding items of each subscale were summed to set a consistent and reliable criterion for inferential statistics for all categories proposed by Uzunboylu and Özdaml1 (2011). Likewise, the mean scores for all items were exclusively summed to develop cut-off points for the descriptive analyses needed for item by item analysis of the participants' overall perceptions of m-learning as well as the three indicators in the scale. The perfect scores obtained for each participant range from 26 to 130. Based on the self-developed cut-off points, the scores were considered as High if they were in the upper third of the normative distribution (96-130), Moderate if they were in the middle third (61-95), and Low if they were in the lower third (26-60). Similarly, the obtained mean scores for all items were exclusively summed to develop cut-off points for the descriptive analyses needed for item by item analysis of the participants' overall perceptions of m-learning as well as the three dimensions. The cut-off points were Low (0-1), Moderate (1-3), and High (3 and above). The GPA cut-off points were Low (0-1), Moderate (1-3), and High (3-4). Descriptive statistics were employed to characterize the participants' perceptions of m-learning, while inferential statistics tests such as MANOVA and regression analysis were used to determine and explain the probable differences among participants' perceptions of m-learning with respect to gender, grade level and GPA (Tabachnick \& Fidell, 2013).

\section{Results}

The present study sought to investigate EFL preservice teachers' perceptions of mobile assisted language learning, find out whether their perceptions differed significantly by gender, grade level and GPA, and determine whether gender, grade level and GPA variables would predict their mobile language learning perceptions. This section presents the results of the study in terms of descriptive and inferential statistics, followed by a discussion of the findings. The findings of the qualitative data are also presented.

\subsection{Preservice English Teachers' Perceptions of Mobile Assisted Language Learning}

The results of descriptive analyses revealed that all the participants rated the items positively within all three subscales since the mean scores for all corresponding items were within the upper third of the normative distribution (3-4). Furthermore, as shown in Table 2, the results for A-MTF factor indicated that the highest mean score $(M=4.09, S D=.97)$ was obtained for item 1 (M-learning tools remove the limitation of time and space) while the lowest mean score $(M=3.68, S D=1.12)$ was received for item 23 (M-learning technologies can be used as a supplement to language learning and teaching at all levels of education). Similarly, the results for Appropriateness of Branch subscale revealed that the highest mean score $(M=4.08, S D=.97)$ was observed for item 9 (M-learning applications facilitate language learning and teaching) whereas the lowest mean score $(M=$ $3.76, S D=1.01$ ) was ascribed to item 15 (M-learning applications are reliable for personal use) in $\mathrm{AB}$ factor. Finally, the results of descriptive analyses for FMA\&TSAC subscale also reported the highest mean score $(M=$ $4.08, S D=1.09$ ) for item 26 (Students can have more effective communication with mobile technologies than traditional methods), and the lowest mean score $(M=3.61, S D=1.19)$ for item 15 (M-learning applications are reliable for personal use). 
Table 2. Descriptive statistics for preservice English teachers' perceptions

\begin{tabular}{l}
\hline Items and Item Descriptions \\
\hline I. A-MTF-Aim-Mobile Technologies Fit \\
1. M-learning tools remove the limitation of time and space. \\
2. Mobile-based language learning applications create effective learning-teaching environments. \\
5. Applications such as Messenger, Skype, Facebook and Twitter provide opportunities to use \\
authentic language without the limitation of time and space. \\
8. An effective learning environment could be provided by sending lecture notes, words and \\
their pronunciations via M-learning tools such as e-mail, MMS or SMS. \\
11. M-learning technology is an effective method in exact transmission of knowledge in \\
learning activities.
\end{tabular}

13. Utilization of m-learning technologies increases students' motivation towards language learning.

20. M-learning systems increase the quality of lessons.

Mean SD

4.09

.97

$4.04 \quad 1.03$

3.97

23. M-learning technologies can be used as a supplement to language learning and teaching at all levels of education.

II: AB-Appropriateness of Branch

4. I can use M-learning applications in order to help my students to get motivated to participate in language learning activities.

9. M-learning applications facilitate language learning and teaching.

10. M-learning applications serve a good method in the target language learning and teaching.

14. Thanks to mobile technologies, I can have a prompt access to the language teaching/ learning materials that I need.

15. M-learning applications are reliable for personal use.

17. M-learning application is a good method for the interaction, which is necessary in language classes.

18. M-learning applications are convenient to share some useful language teaching tasks with my colleagues.

21. I would like to supplement my classes in future with M- learning method.

24. M-learning applications provide a convenient environment to have discussions about language learning and teaching topics.

III: FMA and TSAC-Forms of M-learning Application \& Tools' Sufficient Adequacy of Communication

3. Language learning and teaching process should be supported with mobile-learning applications.

6. M-learning applications can be used to supplement the traditional education.

7. Mobile language learning applications can generate real-world, communicative tasks for language learners.

12. Teacher-student communication is facilitated by means of m-learning tools.

16. Communication is possible in chat programs by means of mobile technologies.

19. Course materials can be sent to students via MMS.

22. Student-student communication is facilitated by means of M-learning tools.

25. Learners can access the instructional websites with mobile technologies.

26. Students can have more effective communication with mobile technologies than traditional methods.

Additionally, more than two-third of the participants (75\%) agreed with overall attitudes towards mobile assisted language learning. More specifically, 79.43\% agreed with A-MTF dimension, $76.11 \%$ with AB dimension and $73.96 \%$ with FMA dimension of m-learning perceptions. A careful examination indicates that most participants 
had positive perceptions about m-learning applications with specific assertion on the effectiveness of these devices in removing time and space limitations in language learning, facilitative function of m-learning, and the superiority of mobile devices over traditional methods in learning EFL. Therefore, preservice EFL teachers' acceptance or positive perceptions of m-learning technologies are among the most important issues in integrating new mobile devices such as tablets or smartphones into ongoing instructional practices in the EFL classroom.

The results of descriptive analyses for between subjects factors indicated that the highest mean scores $(M=$ $37.96, S D=3.50)$ for AB subscale, $(M=37.25, S D=3.51)$ for FMA\&TSAC subscale, and $(M=108.14, S D=$ 9.49) for overall perceptions of m-learning were received by females with higher GPA, whereas the same mean score for A-MTF subscale $(M=32.93, S D=3.49)$ was observed among females with higher GPA and males with moderate GPA. All the highest mean scores were ascribed to third grade in females group while the only highest mean score for males occurred in fourth grade (Table 3).

Table 3. Descriptive statistics for between-subjects effects

\begin{tabular}{|c|c|c|c|c|c|c|}
\hline Variables & Gender & Grade & GPA & $N$ & Mean & $S D$ \\
\hline \multirow[t]{8}{*}{ A-MTF } & \multirow[t]{4}{*}{ Female } & \multirow[t]{2}{*}{ 3rd year } & Moderate & 19 & 31.68 & 5.94 \\
\hline & & & High & 28 & 32.93 & 3.49 \\
\hline & & \multirow[t]{2}{*}{4 th year } & Moderate & 33 & 32.73 & 5.31 \\
\hline & & & High & 76 & 31.59 & 6.81 \\
\hline & \multirow[t]{4}{*}{ Male } & \multirow[t]{2}{*}{ 3rd year } & Moderate & 8 & 21.75 & 9.79 \\
\hline & & & High & 2 & 31.50 & 2.12 \\
\hline & & \multirow[t]{2}{*}{4 th year } & Moderate & 15 & 32.93 & 4.66 \\
\hline & & & High & 20 & 31.25 & 3.61 \\
\hline \multirow[t]{8}{*}{$\mathrm{AB}$} & \multirow[t]{4}{*}{ Female } & \multirow[t]{2}{*}{ 3rd year } & Moderate & 19 & 35.32 & 6.01 \\
\hline & & & High & 28 & 37.96 & 3.50 \\
\hline & & \multirow[t]{2}{*}{4 th year } & Moderate & 33 & 36.45 & 6.12 \\
\hline & & & High & 76 & 36.04 & 7.77 \\
\hline & \multirow[t]{4}{*}{ Male } & \multirow[t]{2}{*}{ 3rd year } & Moderate & 8 & 23.88 & 13.70 \\
\hline & & & High & 2 & 34.00 & 1.41 \\
\hline & & \multirow[t]{2}{*}{ 4th year } & Moderate & 15 & 37.60 & 4.76 \\
\hline & & & High & 20 & 34.20 & 4.43 \\
\hline \multirow[t]{8}{*}{ FMA \& TSAC } & \multirow[t]{4}{*}{ Female } & \multirow[t]{2}{*}{ 3rd year } & Moderate & 19 & 35.37 & 7.14 \\
\hline & & & High & 28 & 37.25 & 3.51 \\
\hline & & \multirow[t]{2}{*}{ 4th year } & Moderate & 33 & 37.03 & 5.43 \\
\hline & & & High & 76 & 35.46 & 7.33 \\
\hline & \multirow[t]{4}{*}{ Male } & \multirow[t]{2}{*}{ 3rd year } & Moderate & 8 & 23.13 & 12.13 \\
\hline & & & High & 2 & 35.50 & 2.12 \\
\hline & & \multirow[t]{2}{*}{ 4th year } & Moderate & 15 & 35.40 & 5.15 \\
\hline & & & High & 20 & 34.40 & 4.33 \\
\hline \multirow[t]{8}{*}{ Overall } & \multirow[t]{4}{*}{ Female } & \multirow[t]{2}{*}{ 3rd year } & Moderate & 19 & 102.37 & 18.80 \\
\hline & & & High & 28 & 108.14 & 9.49 \\
\hline & & \multirow[t]{2}{*}{4 th year } & Moderate & 33 & 68.75 & 35.25 \\
\hline & & & High & 76 & 101.00 & 1.41 \\
\hline & \multirow[t]{4}{*}{ Male } & \multirow[t]{2}{*}{ 3rd year } & Moderate & 8 & 68.75 & 35.25 \\
\hline & & & High & 2 & 101.00 & 1.41 \\
\hline & & \multirow[t]{2}{*}{ 4th year } & Moderate & 15 & 105.93 & 13.30 \\
\hline & & & High & 20 & 99.85 & 10.95 \\
\hline
\end{tabular}




\subsection{Differences of Perceptions of MALL in Terms of Gender, Grade Level, and GPA}

The two-way multivariate analysis of variance (two-way MANOVA) was conducted to see how the participants' perceptions about mobile language learning differ by gender, GPA, and grade level (third or fourth year). The results indicated a significant main effect for their gender and perceptions of m-learning (Wilks' Lambda $=.956$, $F(3,191)=2.898, p=0.036, p<.05$, partial $\eta^{2}=.044$ and power to detect the effect $\left.=.685\right)$. However, the results revealed no significant main effect between grade and GPA factors, and m-learning perceptions. There was also a significant interaction effect between gender and GPA factors on the m-learning perception levels (Wilks' $\lambda=.956, F(3,191)=2.825, p=0.040, p<.05$, partial $\eta^{2}=.042$ and power to detect the effect $=.672$ ). As indicated in Table 4, however, no significant interaction effect was found for gender and grade, and grade and GPA.

Table 4. Interaction effect of gender, grade and GPA variables on perceptions of m-learning

\begin{tabular}{|c|c|c|c|c|c|c|c|c|c|c|c|c|}
\hline \multirow{3}{*}{ Variables } & \multicolumn{12}{|c|}{ Two-way MANOVA } \\
\hline & \multicolumn{6}{|c|}{ Main Effect } & \multicolumn{6}{|c|}{ Interaction Effect } \\
\hline & $\lambda$ & $d f$ & $\mathrm{~F}$ & Sig. & $\mathrm{y}^{2}$ & power & $\lambda$ & $d f$ & $\mathrm{~F}$ & Sig. & $\mathrm{y}^{2}$ & Power \\
\hline Gender & .956 & $3 ; 191$ & 2.898 & $.036^{*}$ & .044 & 685 & - & - & - & - & - & \\
\hline Grade & .977 & $3 ; 191$ & 1.471 & .224 & .023 & 385 & - & - & - & - & - & \\
\hline GPA & .978 & $3 ; 191$ & 1.459 & .227 & .022 & 383 & & & & & & \\
\hline Grade*Gender & - & - & - & - & - & - & .971 & $3 ; 191$ & 1.920 & .128 & .029 & .491 \\
\hline Gender*GPA & - & - & - & - & - & & .958 & $3 ; 191$ & 2.825 & $.040^{*}$ & .042 & .672 \\
\hline Grade *GPA & & & & & & & .961 & $3 ; 191$ & 2.606 & .053 & .039 & .633 \\
\hline
\end{tabular}

* Significant at .05 level.

** Significant at .01 level.

The results of tests of between-subjects effects, or univariate tests, revealed that there were significant differences between males and females across all levels of m-learning perception while the participants differed significantly in subscales of $\mathrm{AB}$ and overall perceptions by grade. Besides, the participants' perceptions about m-learning showed significant differences in the interaction effect of gender and grade on A-MTF and AB subscales and in overall perceptions, while significant differences were observed between participants' in grade*GPA interaction effect on all dimensions of overall m-learning perception (Table 5).

Table 5. Relationship between gender, grade and GPA and m-learning perception levels

\begin{tabular}{lllllll}
\hline \multirow{2}{*}{ Variables } & \multirow{2}{*}{ Subscales } & \multicolumn{6}{l}{ Two-way MANOVA } \\
\cline { 3 - 7 } & & $d f$ & F & Sig. & y2 & Observed Power \\
\hline Gender & A-MTF & $1 ; 193$ & 4.442 & $.036^{*}$ & .022 & .555 \\
& AB & $1 ; 193$ & 6.563 & $.011^{*}$ & .033 & .722 \\
& AMA & $1 ; 193$ & 7.693 & $.006^{* *}$ & .038 & .788 \\
Grade & Overall & $1 ; 193$ & 6.671 & $.011^{*}$ & .033 & .729 \\
& A-MTF & $1 ; 193$ & 3.803 & .053 & .019 & .492 \\
& AB & $1 ; 193$ & 4.371 & $.038^{*}$ & .022 & .548 \\
GPA & FMA \& TSAC & $1 ; 193$ & 3.373 & .068 & .017 & .447 \\
& Overall & $1 ; 193$ & 4.126 & $.044^{*}$ & .021 & .524 \\
& A-MTF & $1 ; 193$ & 2.245 & .136 & .012 & .320 \\
& AB & $1 ; 193$ & 2.032 & .156 & .010 & .294 \\
& FMA \& TSAC & $1 ; 193$ & 3.775 & .053 & .019 & .489 \\
& Overall & $1 ; 193$ & 2.826 & .094 & .014 & .387 \\
\hline
\end{tabular}




\begin{tabular}{lllllll}
\hline Gender*Grade & A-MTF & $1 ; 193$ & 4.234 & $.041^{*}$ & .021 & .535 \\
& AB & $1 ; 193$ & 5.480 & $.020^{*}$ & .028 & .644 \\
& FMA \& TSAC & $1 ; 193$ & 3.530 & .062 & .018 & .464 \\
& Overall & $1 ; 193$ & 4.718 & $.031^{*}$ & .024 & .580 \\
Gender*GPA & A-MTF & $1 ; 193$ & 2.127 & .146 & .011 & .306 \\
& AB & $1 ; 193$ & .511 & .476 & .003 & .110 \\
Grade*GPA & FMA \& TSAC & $1 ; 193$ & 3.382 & .067 & .017 & .448 \\
& Overall & $1 ; 193$ & 1.881 & .172 & .010 & .276 \\
& A-MTF & $1 ; 193$ & 6.409 & $.012^{*}$ & .032 & .712 \\
Gender*Grade*GPA & AB & $1 ; 193$ & 6.968 & $.009^{* *}$ & .035 & .747 \\
& FMA \& TSAC & $1 ; 193$ & 7.824 & $.006^{* *}$ & .039 & .795 \\
& Overall & $1 ; 193$ & 7.588 & $.006^{* *}$ & .038 & .783 \\
& AB & $1 ; 193$ & 2.754 & .099 & .014 & .379 \\
& FMA \& TSAC & $1 ; 193$ & 2.771 & .098 & .014 & .381 \\
& Overall & $1 ; 193$ & 2.948 & .088 & .015 & .401 \\
\hline
\end{tabular}

* Significant at .05 level.

** Significant at .01 level.

\subsection{Gender, Grade Level and GPA as Predictors of M-Learning Perceptions}

The results of multiple regression analysis, enter method, for determining the potential relationship between the three factors reflecting preservice teachers' perceptions of m-learning and their gender, grade level and GPA were statistically significant for A-MTF dimension, $F_{(3,197)}=2.693 ; p=0.047, p<0.05$, Appropriateness of Branch, $F_{(3,197)}=3.637 ; p=0.014, p<0.05$, FMA \& TSAC, $F_{(3,197)}=5.157 ; p=0.002, p<0.05$, and overall perceptions, $F_{(3,197)}=40.40 ; p=0.008, p<0.05$ (Table 6).

Table 6. Relationship between m-learning perception levels and gender, grade, and GPA

\begin{tabular}{llllll}
\hline \multirow{2}{*}{ Subscales } & \multicolumn{4}{l}{ ANOVA } & \\
\cline { 2 - 6 } & $N$ & Mean Square & $d f$ & $F$ & Sig.(2-tailed) \\
\hline A-MTF & 201 & 98.14 & 3,197 & 2.693 & $0.047^{*}$ \\
AB & 201 & 177.07 & 3,197 & 3.637 & $0.014^{*}$ \\
FMA \& TSAC & 201 & 228.24 & 3,197 & 5.157 & $0.002^{* *}$ \\
Overall perceptions & 201 & 4390.12 & 3,197 & 4.040 & $0.008^{* *}$ \\
\hline
\end{tabular}

*Significant at 0.05 level

** Significant at 0.01 level

The stepwise multiple regression analyses were conducted to determine which variables better predict the participants' perceptions (Table 7). The results revealed that GPA was the strongest predictor of the participants' perceptions on m-learning. GPA was the only predictor of perceptions in A-MTF dimension, $F_{(1,199)}=5.060 ; p=$ $0.026, p<0.05 ; \mathrm{t}=2.249, p=0.026, p<0.05$ and $\mathrm{AB}$ dimension, $(1,199)=6.380 ; p=0.012, p<0.05 ; \mathrm{t}=2.526$, $p=0.012, p<0.05$. GPA was also found to be the strongest predictor of the participants' perceptions of FMA\&TSAC, $F_{(1,199)}=9.070 ; p=0.003, p<0.05 ; \mathrm{t}=2.451, p=0.015, p<0.05$ and overall perceptions of m-learning, $F_{(1,199)}=7.248 ; p=0.008, p<0.05 ; \mathrm{t}=2.204, p=0.029, p<0.05$, while gender was the second strongest predictor of the participants' perceptions of FMA\&TSAC, $F_{(1,199)}=7.371 ; p=0.001, p<0.05 ; \mathrm{t}=$ $-2.339, p=0.020, p<0.05$, and overall perceptions of m-learning, $F_{(1,199)}=5.651 ; p=0.004, p<0.05 ; \mathrm{t}=-1.987$, $p=0.048, p<0.05$. These findings indicate preservice EFL teachers' perceptions of m-learning are predictable and can be captured through careful investigation of the relationship between such factors as gender and their 
academic achievement level, and attitudes towards m-learning applications. This can provide insights for language departments to offer courses based on m-learning applications through needs analysis and deciding on to whom this m-learning-based curriculum is thought necessary and would yield promising results.

Table 7. Coefficients of $A-M T F, A B$, and $F M A \& T S A C$ and predictors of m-learning perceptions

\begin{tabular}{llllllllll}
\hline \multirow{2}{*}{ Variables } & \multicolumn{2}{l}{ A-MTF } & \multicolumn{3}{c}{ AB } & \multicolumn{3}{c}{ FMA \& TSAC } \\
\cline { 2 - 10 } & Beta & $\mathrm{t}$ & Sig. & Beta & $\mathrm{t}$ & Sig. & Beta & $\mathrm{t}$ & Sig. \\
\hline 1. Gender & -.111 & -1.541 & .125 & -.144 & -2.017 & $.045^{*}$ & -.164 & -2.339 & $.020^{*}$ \\
2. GPA & .157 & 2.429 & $.026^{*}$ & .176 & 2.526 & $.012^{*}$ & .172 & 2.451 & $.015^{*}$ \\
\hline
\end{tabular}

\subsection{Results of Qualitative Data}

Overall, all the interviewees expressed their positive attitudes toward the use of mobile language learning. The results revealed that based on the notion of ubiquity or anywhere and anytime, mobile language learning can promote autonomous learning by providing them opportunities to enhance their vocabulary and grammar as well as their L2 skills. For example, one of the students said, "I have been using mobile apps such as dictionaries for a few years. I have benefited them both in and outside the classroom." Another student said that she would go to a university in Denmark the following year as an Erasmus exchange student and used a smartphone app called "Sproghjælp" to study basic Danish grammar and vocabulary. Most favored mobile devices for listening, speaking and vocabulary study, and they were active users of podcasts typically consisting of audio and video files. However, their opinions often tended to equate m-learning with the use of smartphone apps or table PCs that learners could use to get the content outside the classroom.

The results of the interviews also indicated that today m-learning has some challenges for English teaching in the country. An often expressed concern was the cost of quality functional mobile devices such as smartphones and tablets. Another drawback was related to the lack of devices and connectivity. One student, for example, said, "In future, I want to implement m-learning in English teaching, but I am not so optimistic about whether my students and I will be able to integrate mobile learning technology into my classroom." This skeptical attitude was emphasized by another student who stated that there should be more specifically developed L2 applications and training for the effective use of these language tools in teaching languages. In brief, these student-teachers are already engaged in mobile language learning and aware of its potentials but cautious about some challenges it poses.

\section{Discussion}

This study sought to investigate mobile assisted language learning perceptions of preservice EFL teachers, to find out if there are differences in their perceptions by gender, grade level and GPA, and to determine whether gender, grade level and GPA would predict their perceptions of mobile assisted language learning.

An overwhelming majority of preservice English teachers think m-learning has great potentials to contribute to effective L2 instruction. This can be attributed to the fact that mobile technology has become an indispensable part of people in the world that "is becoming a mobigital virtual space where people can learn and teach digitally anywhere and anytime" (Şad \& Göktaş, 2013, p. 1). The most positive ratings were attributed to the capability of m-learning technology to remove time and space limitations, increase learners' interest and motivations towards language learning, create more effective learning environments, and facilitate knowledge transmission. This implies that m-learning technology can provide teachers with substantial time and space to make use of mobile language learning applications in order to create effective learning-teaching settings. As supplementary tools to L2 instruction, m-learning technology enables learners to transmit notes and knowledge effectively through using such features of m-learning tools as e-mail, MMS or SMS which, in turn, enable teachers to increase students' motivation towards language learning and enhance the ease and quality of knowledge transfer and retention.

Despite some studies reporting low perceptions among prospective teachers regarding m-learning applications (Serin, 2012), little or no changes in participants' perceptions either positively or negatively (Wyatt et al., 2010), and general indifference and neutrality (Kinash, Brand, \& Mathew, 2012), there is overwhelming evidence confirming the findings of the present study and the effectiveness of m-learning applications in educational environments (Cheon, Lee, Crooks, \& Song, 2012; Gromik, 2012; Saran et al., 2009, 2012; Uzunboylu \& Özdaml, 2011) and motivating learners towards learning (Cheon et al., 2012; Martin \& Ertzberger, 2013; Pollara 


\section{\& Kee Broussard, 2011).}

The findings also confirmed that a great majority of preservice EFL teachers agreed with appropriateness of m-learning for L2 instruction. Thus, the highest perceptions were related to the facilitative role of m-learning technology in L2 instruction and learning, ease of prompt access to materials, perceived convenience of mobile applications due to their portability which helps teachers to readily share the teaching tasks with other colleagues and the convenient environment they provide for effective communication and discussion on teaching and learning topics. Furthermore, preservice English teachers reported adequate competence and ease in using mobile applications and performing learning tasks. They also expressed their willingness to apply m-learning technology in their future practical teaching. These findings are supported by those of other researchers in m-learning research (Vilberg \& Grönlund, 2013; Wang et al., 2009; Wyatt et al., 2010).

This study also highlighted the role of gender differences in preservice English teachers' attitudes towards the application of mobile technologies in L2 instruction. This impact of gender identity on perceptions of m-learning technology is supported by the findings of several studies on the relationship between gender variable and perceptions of m-learning technology (Broos, 2005; Wang et al., 2009; Uzunboylu \& Özdaml, 2011), with higher perceptions in favor of males. In contrast, the findings of this study regarding gender variable run counter to the findings of Şad and Göktaş, (2013) that revealed that variables such as program/department, grade, and gender are neutral in causing a practically significant difference in student-teachers' views. This may be attributed to the fact that although the researchers did not refer directly to, participants were not aware of the concept of m-learning and that lack of knowledge and awareness of the potentials of m-learning, especially learning through mobile phones, highly moderated their perceptions on m-learning technologies. As for the role of participants' grade in shaping their m-learning perceptions, it was found that participants differed significantly in their perceptions about appropriateness of their domain and overall m-learning perceptions. Third grade female participants had the most positive scores in nearly all dimensions, though it was proved that the grade variable, as a single factor, cannot be considered as a strong predictor.

An outstanding finding distinct from those of other studies about m-learning technology was the interaction effect that gender, grade level and GPA had on preservice English teachers' perceptions of m-learning. When gender and grade factors are involved in the analysis of variance together, they might produce more significant differences among participants than when tested separately. Notwithstanding a significant difference among participants' perceptions of m-learning applications by gender, no interaction effect of gender and GPA was observed on participants' self-report on m-learning perceptions. Moreover, the findings revealed that GPA and gender play a great role in predicting m-learning perceptions among preservice English teachers. These findings have implications for researchers and those who design and implement m-learning in educational centers. One can argue that the effect of multiple variables should be taken into account when investigating the differences among participants in relation to their perceptions because the premature perceptions based on the results of single factor analysis may be misleading and invalid. Also, all three factors proved to play a vital role in preservice English teachers' perceptions of m-learning applications, suggesting that program developers, curriculum planners and others involved in designing and implementing m-learning programs should have a comprehensive knowledge of program objectives, learner needs and the potential factors which might have facilitative or debilitative impact on the outcomes of the program.

Qualitative findings emphasized the importance of m-learning technology as a supplementary tool which, if used appropriately, can enhance successful language learning, both in and outside the classroom. Specifically, mobile devices can be utilized for learning vocabulary and pronunciation. It is believed that m-learning is both functional and time saving, and can promote L2 instruction through such features as dictionary apps and online audio-video resources. Since most students now carry mobile devices with themselves and use devices such as PDAs, mobile phones, mp3 players for entertainment as well as access to information in their daily life, class notes, tasks and knowledge transmission are facilitated via multimedia messages. Student-teachers emphasized that mobile language learning can be very beneficial if it is managed in systematic way. M-learning can be very helpful since it is accessible anywhere and anytime. Of course, one big problem, according to participants, is the fact that the current education system is not yet prepared to offer this kind of education in all parts of the country.

To some interviewees, not every student has a functional mobile device such as a smartphone or tablet. Sometimes mobile devices such as regular cellular phones distract students from engaging in learning activities. This highlights the hot debate in the literature over the tendency to distinguish the difference between smartphones and cellular phones (Çavuş \& İbrahim, 2009; Franklin, 2011; Wang et al., 2009; Wu et al., 2012; Yang, 2012). Since smartphones carry features of both phones and computers, they can be considered as suitable devices for m-learning which possess the potentials to create great enthusiasm and interest in using m-learning 
applications. In Şad and Göktaş’s (2013, p. 10) words, "Probably in very near future, most of the people might only use one device and most likely that will be the smartphone. Thus, the participants' perceptions about limitations (e.g., memory size and cost) and poor m-learning potentials (e.g., access to info, individualized learning, lifelong learning, learning everyday and anytime, etc.) of m-phones should be interpreted carefully."

\section{Conclusions and Recommendations}

This study explored preservice English teachers' perceptions of mobile assisted language learning (MALL) in a Turkish setting. While the participants positively rated 26 items in m-learning questionnaire, the findings revealed significant differences among the participants in terms of their perceptions towards the suitability and effectiveness of integrating MALL into EFL classrooms and the possibility of offering courses in m-learning for training preservice English teachers in advance. These positive perceptions and attitudinal representations are the most powerful incentives for administration to adopt MALL. Females showed higher perceptions about m-learning technology in EFL classes since they feel they can achieve more satisfactory results using mobile technology due to the availability, accessibility, portability/mobility, and versatility of these devices. Most participants acknowledge that m-learning technology can eliminate time and space limitations of technology use in language learning by providing opportunities for practicing English, and transmitting knowledge and skills in and outside classrooms.

Drawing upon the findings, integrating m-learning technology in EFL teacher training programs and mainstream language classrooms is now beyond dispute. Most studies on m-learning perception levels of students and teachers from different departments as well as preservice teachers have largely relied on participants' perceptions of m-learning based on regular cellular phones with more limited features than others. Therefore, for future research it may be more beneficial to put more weight on the technical features and capabilities of smartphones on the premises that they have direct and promising bearings on effective learning. Moreover, gender identity, academic level of participants and their GPA should be considered in conducting research, evaluating and generalizing the findings. What is of utmost importance in this study is the interaction effect of variables on participants' m-learning perception levels which have been taken for granted in previous studies. Therefore, future studies will be more informative if they focus on both the main effects of the variables affecting perceptions separately and their interaction effects taken together.

Despite the benefits, some participants stressed the importance of teacher supervision and counseling which, in fact, necessitates teachers to get trained in using m-learning technology. Therefore, the best place to start is to raise awareness of the faculty responsible for teacher training, and re-structure the aspects of technology, pedagogy, and content knowledge courses in the EFL teacher training curriculum. Departments, faculty, and administration should take useful and constructive measures to raise awareness towards the beneficial aspects of mobile technology among students and teachers, and also bear the burden of designing courses based on the usefulness of the state of the art technologies in m-learning. However, this requires a huge amount of investment, both in human and technical resources.

As in any social research, this study also has limitations. First, the findings are limited by self-report data and interviews. Second, the student-teachers' perception that they were being studied may have led them to articulate high perceptions of m-learning. Therefore, further studies can be conducted to address similar questions in language teacher education programs as well as mainstream EFL programs by focusing on how specific mobile tools integrating with suitable pedagogical strategies can be used to improve students' learning performance.

\section{Acknowledgements}

I would like to thank my colleagues İsmail Hakkı Erten, Mehmet Demirezen, and Jafar Pourfeiz for their valuable comments and suggestions on improving the quality of this study. I am also indebted to the anonymous participants and reviewers of English Language Teaching for their valuable contribution.

\section{References}

Broos, A. (2005). Gender and information and communication technologies (IT) anxiety: Male self-assurance and female hesitation. CyberPsychology \& Behaviour, 8(1), 21-31. http://dx.doi.org/10.1089/cpb.2005.8.21

Çavuş, N., \& İbrahim, D. (2009). M-Learning: An experiment in using SMS to support learning new English language words. British Journal of Educational Technology, 40(1), 78-91.

Cheon, J., Lee, S., Crooks, S. M., \& Song, J. (2012). An investigation of mobile learning readiness in higher education based on the theory of planned behavior. Computers \& Education, 59(3), 1054-1064. http://dx.doi.org/10.1016/j.compedu.2012.04.015 
Chinnery, G. M. (2006). Going to the MALL: Mobile assisted language learning. Language Learning \& Technology, 10(1), 9-16.

Dudeney, G., \& Hockly, N. (2012). ICT in ELT: How did we get here and where are we going? ELT Journal, 66(4), 533-542. http://dx.doi.org/10.1093/elt/ccs050

El-Hussein, M. O. M., \& Cronje, J. C. (2010). Defining mobile learning in the higher education landscape. Educational Technology \& Society, 13(3), 12-21.

Field, A. (2009). Discovering statistics for SPSS. Los Angeles, CA: SAGE Publications.

Franklin, T. (2011). Mobile learning: at the tipping point. Turkish Online Journal of Educational Technology, 10(4), 261-275.

Godwin-Jones, R. (2011). Emerging technologies mobile apps for language learning. Language Learning \& Technology, 15(2), 2-11.

Gromik, N. A. (2012). Cell phone video recording feature as a language learning tool: A case study. Computers \& Education, 58(1), 223-230. http://dx.doi.org/10.1016/j.compedu.2011.06.013

Hockly, N. (2013). Mobile learning. ELT Journal, 67(1), 80-84. http://dx.doi.org/10.1093/elt/ccs064

JISC. (2013). Mobile learning infokit. Retrieved from http://goo.gl/txDkB

Kinash, S., Brand, J., \& Mathew, T. (2012). Challenging mobile learning discourse through research: Student perceptions of blackboard mobile learn and iPads. Australasian Journal of Educational Technology, 28(4), 639-655.

Kukulska-Hulme, A. (2009). Will mobile learning change language learning? ReCALL, 21(2), 157-165.

Kukulska-Hulme, A. (2010). Charting unknown territory: Models of participation in mobile language learning. International Journal of Mobile Learning and Organisation, 4(2), 116-129.

Kukulska-Hulme, A., \& Shield, L. (2008). An overview of mobile assisted language learning: From content delivery to supported collaboration and interaction preview. ReCALL, 20(3), 271-289. http://dx.doi.org/10.1017/S0958344008000335

Martin, F., \& Ertzberger, J. (2013). Here and now mobile learning: An experimental study on the use of mobile technology. Computers \& Education, 68, 76-85. http://dx.doi.org/10.1016/j.compedu.2013.04.021

Motiwalla, L. F. (2007). Mobile learning: A framework and evaluation. Computers \& Education, 49, 581-596. http://dx.doi.org/10.1016/j.compedu.2005.10.011

Özdaml1, F., \& Çavuş, N. (2011). Basic elements and characteristics of mobile learning. Social and Behavioral Sciences, 28, 937-942. http://dx.doi.org/10.1016/j.sbspro.2011.11.173

Park, S. Y., Nam, M.-W., \& Cha, S.-B. (2012). University students' behavioral intention to use mobile learning: Evaluating the technology acceptance model. British Journal of Educational Technology, 43(4), 592-605. http://dx.doi.org/10.1111/j.1467-8535.2011.01229.x

Pollara, P., \& Kee Broussard, K. (2011). Student perceptions of mobile learning: A review of current research. In Proceedings of Society for Information Technology \& Teacher Education International Conference 2011 (pp. 1643-1650). Chesapeake, VA: AACE.

Şad, S. N., \& Göktaş, O. (2013). Preservice teachers' perceptions about using mobile phones and laptops in education as mobile learning tools. British Journal of Educational Technology, 45, 606-618. http://dx.doi.org/10.1111/bjet.12064

Saran, M., \& Seferoğlu, G. (2010). Supporting foreign language vocabulary learning through multimedia messages via mobile phones. Hacettepe University Journal of Education, 38, 252-266.

Saran, M., Seferoğlu, G., \& Çağıltay, K. (2009). Mobile assisted language learning: English pronunciation at learners' fingertips. Eurasian Journal of Educational Research, 34, 97-114.

Saran, M., Seferoğlu, G., \& Çă̆ıltay, K. (2012). Mobile language learning: Contribution of multimedia messages via mobile phones in consolidating vocabulary. The Asia-Pacific Educational Researcher, 21(1), 181-190.

Serin, O. (2012). Mobile learning perceptions of the prospective teachers (TPNR Sampling). Turkish Online Journal of Educational Technology, 11(3), 222-233. 
Sharples, M., Taylor, J., \& Vavoula, G. (2007). A theory of learning for the mobile age. In R. Andrews \& C. Haythornthwaite (Eds.), The Sage handbook of elearning research (pp. 221-247). London: Sage.

Stockwell, G. (2010). Using mobile phones for vocabulary activities: Examining the effect of the platform. Language Learning \& Technology, 14(2), 95-110. Retrieved from http://ltt.msu.edu/vol14num2/stockwell.pdf

Tabachnick, B. G., \& Fidell, L. S. (2013). Using multivariate statistics (6th ed.). Boston, MA: Pearson.

Tai, Y., \& Ting, Y. L. (2011). Adoption of mobile technology for language learning: Teacher attitudes and challenges. The JLAT CALL Journal, 7, 3-18.

Uzunboylu, H., \& Özdaml1, F. (2011). Teacher perception for m-learning: Scale development and teachers' perceptions. Journal of Computer Assisted Learning, 27(6), 544-556. http://dx.doi.org/10.1111/j.1365-2729.2011.00415.x

Vilberg, O., \& Grönlund, Å. (2013). Cross-cultural analysis of users' attitudes toward the use of mobile devices in second and foreign language learning in higher education: A case from Sweden and China. Computers \& Education, 69, 169-180. http://dx.doi.org/10.1016/j.compedu.2013.07.014

Wang, Y. S., Wu, C. M., \& Wang, Y. H. (2009). Investigating the determinants and age and gender differences in the acceptance of mobile learning. British Journal of Educational Technology, 40, 92-118. http://dx.doi.org/10.1111/j.1467-8535.2007.00809.x

Wu, W., Wu, Y. J., Chen, C., Kao, H., Lin, C., \& Huang, S. (2012). Review of trends from mobile learning $\begin{array}{lllll}\text { studies: A meta-analysis. Computers \& Education, 59(2), } & \text { 817-827. }\end{array}$ http://dx.doi.org/10.1016/j.compedu.2012.03.016

Wyatt, T. H., Krauskopf, P. B., Gaylord, N. M., Ward, A., Huffstutler-Hawkins, S., \& Goodwin, L. (2010). Cooperative m-learning with nurse practitioner students. Nursing Education Perspectives, 31(2), 109-112.

Yang, S.-H. (2012). Exploring college students' attitudes and self-efficacy of mobile learning. Turkish Online Journal of Educational Technology, 11(4), 148-154.

\section{Copyrights}

Copyright for this article is retained by the author(s), with first publication rights granted to the journal.

This is an open-access article distributed under the terms and conditions of the Creative Commons Attribution license (http://creativecommons.org/licenses/by/3.0/). 